\title{
Effect of lupin flour incorporation of mechanical properties of corn flour tortillas
}

\author{
Juan Francisco HERNANDEZ-CHAVEZ1 ${ }^{1}$, Norma GUEMES-VERA ${ }^{2 *}$, Marisol OLGUIN-PACHECO², \\ Perla OSORIO-DIAZ ${ }^{3}$, Luis Arturo BELLO-PEREZ ${ }^{3}$, Alfonso TOTOSAUS-SANCHEZ ${ }^{4}$
}

\begin{abstract}
Many people base their food consumption on corn flour tortillas (tortillas), which has deficiencies in protein. For that reason, the aim in this work was to incorporate Lupinus flour, a legume that is high in protein, into maize tortillas, and to evaluate the texture profile analysis (TPA) and adhesiveness in the doughs at various percentages of Lupinus flour addition, including 2.5\%, $5 \%$ and $7.5 \%$. Doughs treated with $2.5 \%, 5 \%$ and $7.5 \%$ Lupinus flour had higher adhesiveness values of $2.84,2.38$ and $4.62 \mathrm{~N}$, respectively. The same effect was observed for the hardness measurements of the same treatments $(2.38,2.56$ and $2.84 \mathrm{~N}$, respectively). Based on the adhesiveness results, the doughs were subsequently used to make tortillas. The lowest tensile strength was found in the $7.5 \%$ treatment, with a value of $3.35 \mathrm{~N}$, and the highest tensile strength was $6.61 \mathrm{~N}$, corresponding to the $2.5 \%$ treatment. Rollability and inflation were good in the samples from the $2.5 \%$ and $7.5 \%$ treatments, without breaks and with full blister formation, while in the $5.0 \%$ treatment, $25 \%$ rupture was observed, and inflation was only medium. The color was light yellow in the $5.0,7.5$, and $2.5 \%$ treatments, which was equal to the control.
\end{abstract}

Keywords: texture; doughs; legumes; adhesiveness; rollability.

Practical Application: In this study used Lupin flour for fortification maize of tortillas, product popular consumption.

\section{Introduction}

Tortillas alone provides $38.8 \%$ of the protein, $45.2 \%$ of the calories and $49.1 \%$ of the calcium in the diet of the general population, and in Mexican rural areas it provides approximately $70 \%$ of the total calories and $50 \%$ of the protein ingested daily (Figueroa Cárdenas et al., 2001; Vázquez Rodríguez \& Amaya Guerra, 2010). Corn proteins are considered to have poor nutritional quality because, in the zein, the main protein fraction of corn, the concentrations of the essential amino acids lysine and tryptophan are low (Paredes-López et al., 2009). Legumes are well suited for protein fortification due to their high protein content. Early research on the tortilla in Mexico was carried out in the 1950s by the National Institute of Nutrition. Subsequently, studies were performed on the fortification of tortillas with soy flour and chickpea flour. It was found that the addition of the limiting amino acids (lysine and tryptophan) improves the nutritional value of the proteins of the tortilla; however, the nutritional value is further improved when corn flour is fortified simultaneously with amino acids and vitamins, such as thiamine and riboflavin (Organización Mundial de la Salud, 2009). In some cases, there have been significant advances; in others, fortification has altered the taste, color or product hardness (Torres et al., 1996). In previous studies on the effect of the addition of white beans on certain nutritional, physicochemical and textural properties of the tortilla, it was found that with the addition of $25 \%$ white bean, the contents of lysine and tryptophan increased from 56 and $36 \%$ of the value of the FAO profile to 95 and $84 \%$, respectively. Moreover, the textural and physicochemical properties of the tortillas that incorporated white bean were similar to those prepared only with corn flour (Cuevas-Martínez et al., 2010). Lupinus species are widely distributed in Mexico (Villavicencio \& Pérez-Escandón, 1998), but there are few studies on the use of native species as a food source (Ruíz \& Sotelo, 2001; México, 2015). Usually, Lupinus is used for its oil, which can be extracted and used as biodiesel (DeHaan et al., 2010; México, 2015). The byproduct of that process is a flour that contains a rich profile of protein and essential amino acids (Day, 2013; Chirinos-Arias, 2015), which can be used in animal feed and food for people (Ortega-David et al., 2010; Paraskevopoulou et al., 2012). However, Lupinus flour must first be detoxified for those uses. Lupinus flour has been tested as an additive to bread, and it was reported that the crumbs made with the flour mixture (Lupinus + wheat) had more moisture than the control (100\% wheat). Additionally, the breadcrumbs containing lupine protein isolate (with and without brea gum) had a lower hardness $\left({ }^{*} \mathrm{P}<0.05\right)$, and this improved its acceptability for $80 \%$ of consumers (Doxastakis et al., 2002). Another study showed that the nutritional, phytochemical and bioactive composition of refined wheat flour bread is significantly improved with the

Received 28 Feb., 2018

Accepted 26 Nov., 2018

${ }^{1}$ Laboratory of Foods, Departamento de Ciencias Agronómicas y Veterinarias, Instituto Tecnológico de Sonora, Obregón, Sonora, México

${ }^{2}$ Area Academica de Ingenieria Agroindustrial e Ingenieria en Alimentos, Instituto de Ciencias Agropecuarias, Universidad Autonoma del Estado de Hidalgo, Tulancingo Hidalgo, Mexico

${ }^{3}$ Centro de Productos Bioticos, Instituto Politécnico Nacional, Col. San Isidro Yautepec Morelos, Mexico

${ }^{4}$ LabßPP de Alimentos/Food Science Lab \& Pilot Plant, Tecnologico Estudios Superiores Ecatepeco, Estado de Mexico, Mexico

${ }^{*}$ Corresponding author: njgv2002@yahoo.com.mx 
addition of Lupinus angustifolius flour, indicating that Lupinus flour/wheat flour bread may have useful nutritional and health functionality (López \& Goldner, 2015). Studies have shown that substituting wheat with Lupinus flour can significantly improve the protein and dietary fiber contents of wheat bread (López \& Goldner, 2015; Villarino et al., 2015). The aim of this study was to evaluate the use of detoxified Lupinus flour to make corn tortillas (tortillas) and to test the nutritional and quality characteristics.

\section{Materials and methods}

Lupinus albus seeds were provided by the Herbarium of the Universidad de Guadalajara, México. Creole maize seeds (Zea mays L) employed in tortilla production were obtained at the Central de Abastos market, in Tulancingo, México during the month of November, two months after the 2015 harvest.

Lupinus detoxification was performed by cooking the seeds in boiling water for $5 \mathrm{~min}$, followed by continuous water washing for $10 \mathrm{~h}$ to eliminate the water-soluble alkaloids (Güémes-Vera et al., 2008). Finally, seeds were dried in an oven at $60^{\circ} \mathrm{C}$ before being milled and sieved through a mesh sieve, no. 80 , to obtain Lupinus flour.

Maize nixtamalization was carried out according to the technique described by Méndez-Montealvo et al. (2008). Maize seeds $(5 \mathrm{~kg})$ were cooked in $15 \mathrm{~L}$ of $1 \%(\mathrm{w} / \mathrm{v})$ lime solution for $30 \mathrm{~min}$ at boiling temperature and subsequently steeped in the same cooking vessel for $15 \mathrm{~h}$. Cooked maize seeds were washed twice with tap water to remove excess lime and then milled and sieved. The nixtamalizated maize batter/paste was stored in polyethylene bags at $4{ }^{\circ} \mathrm{C}$.

\subsection{TortillasTortilla dough elaboration and textural analysis}

Tortillas dough was elaborated by replacing the nixtamalized maize dough with different proportions $(0 \%, 2.5 \%, 5.0 \%$ and $7.5 \%$ ) of Lupinus flour that was $30 \%$ hydrated with water.

The tortilla dough was elaborated replacing the dough of nixtamalized corn with different proportions $(0 \%, 2.5 \%, 5.0 \%$ and $7.5 \%$ ) of Lupinus flour that was hydrated by $30 \%$ with water.

\subsection{Dough texture}

A texture profile analysis test was performed on the dough. A total of $100 \mathrm{~g}$ of dough was compressed in a texture analyzer (TA-HDi, Texture Technologies, New York, USA/Stable Microsystems, Surrey, UK) to half its original height in two consecutive cycles with a $2.54 \mathrm{~mm}$ diameter acrylic probe, at a constant cross-head speed of $1.7 \mathrm{~mm} / \mathrm{s}$ with a $5 \mathrm{~s}$ waiting period. Texture profile parameters were calculated from the force-deformation curves, including hardness (maximum force required to attain a given deformation), adhesiveness (work necessary to overcome the attractive forces between the surface of the food and the probe surface), cohesiveness (strength of the internal bonds making up the body of the product) and springiness (degree to which a product returns to its original shape once it has been compressed).
Dough adhesiveness tests were carried out in the same texture analyzer, employing the SMS/Chen-Hoseney accessory (Texture Technologies Corp., New York). Five grams of dough was placed in the interior of the rig, and force was applied to obtain dough filaments of approximately $4 \mathrm{~mm}$. The same probe attached to the same texture analyzer was employed to compress $50 \%$ of each filament. The Hoseney adhesiveness parameters were calculated from dough stickiness force-time curves, including adhesiveness (area under the curve, defined as dough adhesion work) and stringiness (distance that the sample is extended on probe return, defined as an indicator of sample cohesion/strength), as described by Chen \& Hoseney (1995).

\subsection{Tortillas preparation and analysis}

Tortillas were elaborated with the maize/Lupinus dough mixture in a manual tortilladora machine, model MT15 (5" diameter tortillas, Ecomaqmx, Puebla, México). Raw tortillas were cooked for 30 to $45 \mathrm{~s}$ on each side on a hot griddle at $280 \pm 10^{\circ} \mathrm{C}$. Cooked tortillas were stored in polyethylene bags to maintain moisture levels until further analysis within $24 \mathrm{~h}$ of elaboration.

\subsection{Tortilla composition analysis}

A proximal analysis of the tortillas was performed to determine their moisture content (Association of Official Analytical Chemists, 1995 Official Method 934.01), protein content as total nitrogen (Association of Official Analytical Chemists, 1995 Official Method 955.04), fat content as ethereal extract (Association of Official Analytical Chemists, 1995 Official Method 920.39), and crude fiber content (Association of Official Analytical Chemists, 1995 Official Method 950.02). Carbohydrate content was determined by calculating $100-(\%$ moisture $+\%$ protein $+\%$ fat $+\%$ ash $+\%$ crude fiber). The content of the limiting amino acid lysine incorporated into tortillas by the inclusion of Lupinus flour was calculated; the lysine content primarily came from the lysine content of maize $(2.6 \mathrm{~g} / 100 \mathrm{~g})$ and lupine $(6.6 \mathrm{~g} / 16 \mathrm{~g})$, as indicated by Güémes Vera et al. (2008).

\subsection{Tortillas texture}

The force and deformation of the tortillas samples were determined by puncturing the samples attached between two parallel plates $(10 \mathrm{~mm}$ diameter) with a $40 \mathrm{~mm}$-diameter spherical metal probe (TA-54) attached to a texture analyzer, at a constant speed of $10 \mathrm{~mm} / \mathrm{s}$ and a distance of $10 \mathrm{~mm}$. From the force-deformation curves, the tortillas firmness (maximum force detected before tortillass break apart) and elasticity (distance before tortillass breaks apart) were calculated. Puncture deformation was calculated according to Sobral et al. (2001) (Equation 1):

Puncture deformation $(\%)=\frac{\sqrt{\left(\mathrm{D}^{2}+\mathrm{L}^{2}\right)}-\mathrm{L}}{\mathrm{L}} \times 100$

The stress was perfectly distributed along the film, where $\mathrm{D}$ is probe displacement (elasticity) and $\mathrm{L}$ is the initial film length (radius of the parallel plate cell, $10 \mathrm{~mm}$ ).

Tortillas tensile strength was determined using the same texture analyzer. Tortillas samples were cut to obtain $100 \times 25.1 \mathrm{~mm}$ 
sections, which were fixed in the TA-96 tensile grips and stretched at a constant speed of $2 \mathrm{~mm} / \mathrm{s}$ until breakdown. Tensile strength was calculated by dividing the peak load by the cross-sectional area (tortillas width $\times$ thickness). The elongation percent was calculated as the ratio of the extension values and the initial grip separation multiplied by 100 .

\subsection{Rollability and puffing}

Tortillas samples were rolled around a wooden $\operatorname{rod}(4 \mathrm{~cm}$ diameter) to determinate the breaking degree, according to a subjective scale from 1 to 5 ( $1=$ no breaking, very flexible, $5=$ breaks immediately, cannot be rolled). Additionally, tortillas puffing or inflation during the cooking process was determined, using a subjective three-point scale ( $1=$ complete puffing, approximately $70-100 \% ; 2=$ medium puffing, approximately $40-70 \%$; and $3=$ no puffing, approximately $0-40 \%)$.

\subsection{Instrumental color}

Color was determined with a colorimeter MicrOptix S560 i-LAB, USA. The reading was taken directly on the central portion of the tortillas, rotating the sample $90^{\circ}$ to obtain an average measurement of each sample to report luminosity $\mathrm{L}^{*}$, redness $\mathrm{a}^{*}$, and yellowness $\mathrm{b}^{*}$ of the samples.

\subsection{Experimental design and data analysis}

The effect of the Lupinus flour incorporated into the nixtamalized maize tortillas was evaluated with the following proposed model:

$$
\mathrm{Y}_{\mathrm{i}}=\mu+\alpha_{\mathrm{i}}+\epsilon_{\mathrm{i}}
$$

where $Y_{i}$ represents the experimental results at the $i$ th level of Lupinus flour, $\alpha_{\mathrm{i}}$ is the main effect for the percent of Lupinus flour incorporated; $\boldsymbol{\epsilon}_{\mathrm{i}}$ is the residual error, assuming a Normal distribution with at least mean or variance equal to zero since the model is over-parameterized and constrained. The results were analyzed with the PROC ANOVA procedure using SAS Software v 8.0 (SAS System, Cary, NC, USA). Significant differences between means were determined by the Duncan means test.

\section{Results and discussion}

\subsection{Tortillas composition}

Table 1 shows the results of the proximal composition of maize dough fortified with Lupinus flour. The incorporation of $2.5 \%$ Lupinus flour resulted in significantly $(\mathrm{P}<0.05)$ higher moisture values, and the control sample (no added Lupinus flour) presented the lowest moisture content. From the protein content analysis, samples with $7.5 \%$ Lupinus flour presented significantly $(\mathrm{P}<0.05)$ higher values, and the lowest values were observed, as expected, in the control samples. The incorporation of Lupinus flour resulted in a significantly $(\mathrm{P}<0.05)$ lower fat content. Higher incorporation of Lupinus flour $(>5.0 \%)$ resulted in a significantly $(\mathrm{P}<0.05) 1.17 \pm 0.10$ to $1.74 \pm 0.04$ ash content. Similarly, higher Lupinus flour incorporation resulted in a significantly $(\mathrm{P}<0.05) 1.89 \pm 0.01^{\mathrm{a}}$ higher fiber content. Lower Lupinus flour incorporation $(<2.5 \%)$ resulted in a significantly $(\mathrm{P}<0.05)$ lower carbohydrate content.

The replacement of maize by lupinus was mainly due to the content of amino acids that lupinus has since they satisfy the deficiency that the maize has the lysine is low, the protein content of lupinus is higher in comparison to that of maize, the content of fiber is also improved by adding lupinus. This substitution improvement the sensorial, physical and chemical propierties of final product, the proximate analysis conducted on the fortified tortillas is presented in Table 1. The moisture content of the fortified tortillass ranged from $36.21 \%$ to $35.61 \%$. According to Gutiérrez-Dorado et al. (2010), the moisture content of tortillass typically ranges between $35 \%$ and $50 \%$, depending on the conditions that occur during nixtamalization. Moreover, the variety of corn used also affects moisture. The moisture values in tortillass fortified with white bean were reported to be between $47.11 \%$ and $48.16 \%$, which were higher than the values obtained in this study (Cuevas-Martínez et al., 2010).

As expected, the addition of Lupinus flour increased the protein content of the final product (10.45\% to $12.02 \%)$. This increase was due to the high protein content of Lupinus flour $(42.63 \%)$, which is superior to grains, and which may serve to increase the levels of essential amino acids in which maize is deficient. This effect was observed in studies conducted by Figueroa Cárdenas et al. (2001) on soy tortillass fortified at a level of $4 \%$, which reported a $3 \%$ increase in protein compared to the Nixtamal Tortilla (10.91\%). Likewise, (Rendón-Villalobos et al., 2012) observed a similar effect with the addition of chia flour (Salvia hispanica L.), obtaining protein content values of $9.41 \%$ to $12.48 \%$, at flour replacement levels of 5 to $20 \%$, respectively.

No significant differences in lipid content were found with the addition of Lupinus flour ( $\mathrm{p}>0.05$ ), with lipid values of $4.39 \%$ to $4.12 \%$ obtained. The ash content was higher in the fortified tortillas due to the minerals present in Lupinus, including calcium ( 1.5 to $2.2 \mathrm{~g} / \mathrm{kg}$ ), magnesium and potassium.

Table 1. Proximal Analysis of maize tortilla with Lupinus flour.

\begin{tabular}{ccccccc}
\hline $\begin{array}{c}\text { \% of Lupinus flour } \\
(\mathrm{w} / \mathrm{w})\end{array}$ & $\begin{array}{c}\text { Moisture } \\
(\%)\end{array}$ & $\begin{array}{c}\text { Protein } \\
(\%)\end{array}$ & $\begin{array}{c}\text { Fat } \\
(\%)\end{array}$ & $\begin{array}{c}\text { Ash } \\
(\%)\end{array}$ & $\begin{array}{c}\text { Fiber } \\
(\%)\end{array}$ & $\begin{array}{c}\text { Carbohydrates } \\
(\%)\end{array}$ \\
\hline 0.0 & $33.07 \pm 0.53^{\mathrm{d}}$ & $9.60 \pm 0.06^{\mathrm{d}}$ & $4.50 \pm 0.23^{\mathrm{a}}$ & $1.17 \pm 0.10^{\mathrm{c}}$ & $1.5 \pm 0.06^{\mathrm{d}}$ & $47.82^{\mathrm{a}}$ \\
2.5 & $36.21 \pm 0.61^{\mathrm{a}}$ & $10.45 \pm 0.10^{\mathrm{c}}$ & $4.39 \pm 0.07^{\mathrm{b}}$ & $1.40 \pm 0.04^{\mathrm{b}}$ & $1.64 \pm 0.03^{\mathrm{c}}$ & $45.68^{\mathrm{a}}$ \\
5.0 & $35.61 \pm 0.47^{\mathrm{b}}$ & $11.25 \pm 1.40^{\mathrm{b}}$ & $4.29 \pm 0.16^{\mathrm{c}}$ & $1.71 \pm 0.07^{\mathrm{a}}$ & $1.77 \pm 0.01^{\mathrm{b}}$ & $48.17^{\mathrm{b}}$ \\
7.5 & $35.08 \pm 0.05^{\mathrm{c}}$ & $12.02 \pm 0.25^{\mathrm{a}}$ & $4.12 \pm 0.04^{\mathrm{d}}$ & $1.74 \pm 0.04^{\mathrm{a}}$ & $1.89 \pm 0.01^{\mathrm{a}}$ & $55.16^{\mathrm{c}}$ \\
\hline
\end{tabular}

a,b,c,d Means with different letters within the same column differ significantly $(\mathrm{P}<0.05)$. 
For fiber content, the tortillas tested in this study had lower values compared to those reported in previous studies, which reported $1.87 \%$ in nixtamalized tortillas, and $2.39 \%$ in tortillas fortified with $4 \%$ soybean meal. Those studies noted that the full use of all parts of the grain caused an increase in the nutritional value of the tortilla.

\subsection{Dough texture}

In the textural profile analysis, the incorporation of $7.5 \%$ of Lupinus flour resulted in a significantly $(\mathrm{P}<0.05)$ harder dough texture. Similarly, the higher percentage of Lupinus flour incorporation $(7.5 \%)$, resulted in significantly $(\mathrm{P}<0.05)$ higher dough adhesiveness. The incorporation of Lupinus flour into tortillas significantly decreased $(\mathrm{P}<0.05)$ the dough cohesiveness and springiness (Table 2). In the Hoseney test, the incorporation of Lupinus flour significantly decreased $(\mathrm{P}<0.05)$ dough adhesiveness; however, in contrast, the incorporation of Lupinus flour significantly $(\mathrm{P}<0.05)$ increased the dough stringiness (Table 2).

Dough texture is critical in the tortillas-making process. When the dough has the right texture, it is sticky enough to adhere to the rolling mills of the tortilla machine and separate properly, a property influenced by processing conditions, such as temperature and cooking time. Over-cooking produces very adhesive dough that is difficult to handle and becomes overly sticky; under-cooking produces an inadequate tortilla texture consisting of non-cohesive dough that does not form or bind. Dough from NCF (nixtamalized corn flour) is less cohesive than NFCM (nixtamalized fresh corn dough) (Gasca-Mancera \& Casas-Alencáster, 2007).

Table 2 shows the texture profile analysis of dough with the blend of corn and Lupinus flours. As the percentage of Lupinus increased in the blend, the hardness and cohesiveness increased, and the adhesiveness decreased. The increase in hardness and cohesiveness is related to the protein content of Lupinus, and the decrease in adhesiveness is due to the lower starch content present in the blends with increased Lupinus content. The TPA results of the dough fortified with Lupinus flour showed that such a blend can be appropriate for making tortillas.

Previous studies (Flores-Farías, 2004; Bedolla \& Rooney, 1984) conducted on tortillas with added fiber sourced from wheat, soybeans and oats showed that increasing the fiber content diminished the adhesiveness and cohesiveness, likely due to a dilution effect on the starch. Acceptable hardness values of 209 to $530 \mathrm{gf}(2.06 \mathrm{~N}$ to $5.19 \mathrm{~N})$ in dough made with native maize varieties were reported, and the values obtained in this study are within that range.

\subsection{Tortilla texture}

The incorporation of Lupinus flour (2.5\% to 5.0\%) resulted in significantly $(\mathrm{P}<0.05)$ greater firmness and elasticity. When $2.5 \%$ Lupinus flour was added, the tortillas puncture deformation was significantly $(\mathrm{P}<0.05)$ higher. Similarly, when $2.5 \%$ Lupinus flour was added, the tensile strength was significantly $(\mathrm{P}<0.05)$ higher as well. This resulted in a more rollable and puffable tortillas (Table 3).

Table 3 shows an increase in hardness found in the 2.5\% and $5.0 \%$ treatments. The tortillass hardened due to starch retrogradation, which begins in the tortillas immediately as it begins to cool after being cooked. This quality loss in the tortillas is due to amylose, which degrades faster than amylopectin, which, due to its highly polarized and linear nature, tends to form hydrogen bonds between the hydroxyl groups of adjacent molecules (amylose and amylopectin), causing them to lose their hydration capacity compared to their original state, resulting in a partial shrinkage of the starch. This hardening can also be caused by processes of association with protein, fiber and other chemical components (Gomez et al., 1991; Martínez-Flores et al., 1998; Rangel-Meza et al., 2004). The functional properties of corn (Zea mays) products, including tortillass, are strongly

Table 2. Texture profile analysis and Hoseney adhesiveness of maize dough with Lupinus flour.

\begin{tabular}{|c|c|c|c|c|c|c|}
\hline $\begin{array}{l}\% \text { of Lupinus flour } \\
(\mathrm{w} / \mathrm{w})\end{array}$ & $\begin{array}{c}\text { TPA Hardness } \\
(\mathrm{N})\end{array}$ & $\begin{array}{c}\text { TPA Adhesiveness } \\
(-\mathrm{N})\end{array}$ & TPA Cohesiveness & $\begin{array}{l}\text { TPA Springiness } \\
(\mathrm{cm})\end{array}$ & $\begin{array}{c}\text { Hoseney } \\
\text { Adhesiveness } \\
\text { strength }(\mathrm{N}) \\
\end{array}$ & $\begin{array}{c}\text { Hoseney } \\
\text { Stringiness }(\mathrm{mm})\end{array}$ \\
\hline 0.0 & $2.44 \pm 0.01^{\mathrm{b}}$ & $2.48 \pm 0.19^{c}$ & $0.130 \pm 0.09^{\mathrm{a}}$ & $0.233 \pm 0.06^{\mathrm{a}}$ & $0.196 \pm 0.020^{\mathrm{a}}$ & $0.46 \pm 0.02^{\mathrm{a}}$ \\
\hline 2.5 & $2.38 \pm 0.58^{b}$ & $2.84 \pm 0.13^{\mathrm{b}}$ & $0.122 \pm 0.07^{b}$ & $0.227 \pm 0.01^{b}$ & $0.193 \pm 0.011^{\mathrm{b}}$ & $0.35 \pm 0.85^{b}$ \\
\hline 5.0 & $2.56 \pm 0.28^{b}$ & $2.38 \pm 0.22^{c}$ & $0.116 \pm 0.02^{c}$ & $0.267 \pm 0.08^{b}$ & $0.172 \pm 0.001^{\mathrm{c}}$ & $0.32 \pm 0.02^{c}$ \\
\hline 7.5 & $2.84 \pm 0.85^{\mathrm{a}}$ & $4.62 \pm 0.96^{\mathrm{a}}$ & $0.117 \pm 0.04^{\mathrm{c}}$ & $0.238 \pm 0.04^{\mathrm{b}}$ & $0.155 \pm 0.001^{\mathrm{d}}$ & $0.21 \pm 0.01^{\mathrm{d}}$ \\
\hline
\end{tabular}

a,b,c Means with different letters within the same column differ significantly $(\mathrm{P}<0.05)$.TPA: Texture Profile Analysis.

Table 3. Textural properties (puncture and tension) of maize tortilla with Lupinus flour.

\begin{tabular}{|c|c|c|c|c|c|c|}
\hline $\begin{array}{l}\% \text { of Lupinus flour } \\
(\mathrm{w} / \mathrm{w})\end{array}$ & $\begin{array}{l}\text { Firmness } \\
(\mathrm{N})\end{array}$ & $\begin{array}{l}\text { Elasticity } \\
(\mathrm{mm})\end{array}$ & $\begin{array}{c}\text { Puncture } \\
\text { deformation (\%) }\end{array}$ & $\begin{array}{l}\text { Tensile Strength } \\
(\mathrm{N})\end{array}$ & Rollability & Puffing or Inflation \\
\hline 0.0 & $56.54 \pm 0.85^{\mathrm{b}}$ & $7.00 \pm 0.62^{b}$ & $22.89 \pm 1.54^{\mathrm{b}}$ & $4.62 \pm 0.45^{c}$ & 1 & 1 \\
\hline 2.5 & $63.59 \pm 0.17^{\mathrm{a}}$ & $8.14 \pm 0.88^{\mathrm{a}}$ & $24.25 \pm 1.35^{\mathrm{a}}$ & $6.61 \pm 0.13^{\mathrm{a}}$ & 2 & 2 \\
\hline 5.0 & $64.79 \pm 0.12^{\mathrm{a}}$ & $8.17 \pm 0.99^{\mathrm{a}}$ & $17.35 \pm 1.64^{c}$ & $5.57 \pm 0.54^{\mathrm{b}}$ & 1 & 1 \\
\hline 7.5 & $43.39 \pm 0.56^{c}$ & $6.78 \pm 0.77^{\mathrm{b}}$ & $17.24 \pm 1.01^{\mathrm{c}}$ & $3.35 \pm 0.12^{\mathrm{d}}$ & 1 & 1 \\
\hline
\end{tabular}

a,b,c,d Means with different letters within the same column differ significantly $(\mathrm{P}<0.05)$. 
influenced by starch, as opposed to other cereals, such as wheat (Triticum aestivum), which mainly derive their characteristics from proteins (Rodríguez-Sandoval et al., 2005). In general, the texture profile analysis shows no significant differences $(p>0.05)$ between treatments with respect to the control parameters, in terms of hardness, elasticity, cohesiveness and chewiness. Similarly, as a result of the doughs being somewhat adhesive, they dried out faster, and, therefore, the tortillas hardened. Consequently, moisture plays an important role. Agama-Acevedo et al. (2004) reported that tortillass with low humidity are rigid, which may have occurred in the $2.5 \%$ treatment in the present study, which, at $33.07 \%$, had the lowest humidity value. While the moisture of tortillass typically ranges between 35 and $50 \%$, according to Rendón-Villalobos et al. (2012), the value obtained for the $2.5 \%$ treatment is below this range.

Other investigations conducted with nixtamalized flour corroborate this effect (low humidity in the tortillas requires high shear forces), which translates into a loss of softness and flexibility. Moreover, the presence of Lupinus flour at a higher concentration has a positive effect on the hardening of the tortillas, which can be seen in the reduced hardness found with the $7.5 \%$ treatment due to the Lupinus proteins absorbing a greater amount of water, thus improving the texture of the tortillas. In a similar study, it was found that using soy protein improved the texture of the tortillas since soy protein retains more water (Almeida \& Loyd, 1996).

Elasticity results for the tortillas are shown in Table 3, where it is noted that the elasticity for all treatments was statistically the same ( $p>0.05)$. Tortillas from the $7.5 \%$ treatment was soft, due to the high elasticity distance before rupture, a distance effect that was also observed in the $5.0 \%$ treatment but not in the lower concentrations. This effect is also related to the water absorption capacity of Lupinus flour. Hard tortillass require greater deformation force and exhibit shorter distances before breaking (Suhendro et al., 1999). Table 3 shows the values found for cohesiveness. It was observed that, on the whole, cohesiveness tended to decrease with the addition of Lupinus flour, except in the $5.0 \%$ treatment, which had a higher cohesiveness compared to the other formulations tested (0.405).

Chewiness, which refers to the force required to chew solid food until it is ready to be swallowed, is measured by elasticity. A food with high elasticity has a rubbery texture, while a product with low elasticity is frangible. Table 2 shows the values obtained for chewiness. As the 2.5 and $7.5 \%$ treatments had the lowest values for this parameter, it can be said that those tortillass required less force to chew, which can be interpreted as being soft and pliable tortillass.

\subsection{Rollability and inflation}

The rollability and inflation characteristics of the tortillass prepared in this study are presented in Table 3 . The $2.5 \%$ and $7.5 \%$ treatments showed good rollability and inflation, with no significant differences compared to the control, yielding a value of 1. This means that the tortillass inflated, forming a $100 \%$ bubble and, in the same way, when rolled, the tortillass did not rupture. This was due to a greater absorption of water, which gave the tortillas greater flexibility and superior rollability. Semi-inflation occurred with the $5 \%$ treatment, and, in terms of rollability, researchers found a minor rupture of $25 \%$ with this treatment, according to the established scale Cuevas-Martínez et al. (2010).

In a study by Cuevas et al. 2010, tortillass made from extruded nixtamalized flours showed better rollability when lower concentrations of GP (germ and pericarp) were used. Poor rollability is attributed to high concentrations of GP and a low percentage of moisture, indicating a lower water absorption capacity, which does not facilitate an interaction between the components. These factors result in brittle tortillass.

A study conducted by Cuevas-Martínez et al. (2010) on corn tortillas fortified with beans at higher substitution percentages than those presented in this study obtained good rollability and inflation results. The fact that one of the functional properties of Lupinus is its increased water absorption is reflected in the rollability results.

\subsection{Shear and tensile strength of fortified tortillass}

Shear and tensile strength are the properties of tortillas that determine their degree of hardness. The softer and smoother the tortillas, the less work is required for chewing, and the higher the product quality. The perception of quality is also related to the subjective assessment by the consumer, in terms of elasticity, wherein the force required to tear a tortillas by stretching it simulates tearing it with the hands (Figueroa-Cárdenas et al., 2001). The addition of Lupinus in different proportions had a significant effect $(p<0.05)$ on the tension force in the 5.0\% treatment, compared to the control, resulting in a higher tension force $(1.95 \mathrm{~N})$, which was not observed in the $2.5 \%$ and $7.5 \%$ treatments, for which the values of $1.29 \mathrm{~N}$ and $1.54 \mathrm{~N}$, respectively, were markedly similar to the control (Table 3). Tensile strength values of $1.13 \mathrm{~N}$ have been reported in tortillass with $10 \%$ bean fortification, compared to a control value of $1.11 \mathrm{~N}$ (Cuevas-Martínez et al., 2010), values that are similar to those found in this study. The 5.0 treatment resulted in tortillas that was stronger and had a higher tensile strength, while the 7.5\% and $2.5 \%$ treatments had the lowest values.

The test for shear strength simulates the cutting force of a tooth during chewing. Significant differences were observed among the treatments, with the softest levels recorded for the fortification level of 7.5\%. Lower levels of moisture in the tortilla generally cause both higher tension and shear forces, as observed in the $5.0 \%$ treatment, which presented the lowest moisture value of 33.07\% (Vázquez-Rodríguez et al., 2011).

\subsection{Color characteristics of tortillass with Lupinus}

Finally, the incorporation of Lupinus flour did not significantly $(\mathrm{P}>0.05)$ affect luminosity. Higher Lupinus flour incorporation resulted in significant $(\mathrm{P}<0.05)$ changes in both redness and yellowness (Table 4 ).

From the information outlined in Table 4, it is possible to analyze the values generated for the color of the flour tortillass fortified with Lupinus albus. It can be seen that the $2.5 \%$ treatment was similar to the control in all the determined parameters, in 
Table 4. Instrumental color of maize tortilla with Lupinus flour.

\begin{tabular}{cccc}
\hline $\begin{array}{c}\text { \% of Lupinus } \\
\text { flour }(\mathrm{w} / \mathrm{w})\end{array}$ & $\begin{array}{c}\text { Luminosity } \\
\left(\mathrm{L}^{*}\right)\end{array}$ & $\begin{array}{c}\text { Redness } \\
\left(+\mathrm{a}^{*}\right)\end{array}$ & $\begin{array}{c}\text { Yellowness } \\
\left(+\mathrm{b}^{*}\right)\end{array}$ \\
\hline 0.0 & $75.27^{\mathrm{a}}$ & $1.18^{\mathrm{c}}$ & $21.46^{\mathrm{c}}$ \\
2.5 & $75.54^{\mathrm{a}}$ & $1.34^{\mathrm{b}}$ & $21.48^{\mathrm{c}}$ \\
5.0 & $75.50^{\mathrm{a}}$ & $1.75^{\mathrm{b}}$ & $22.95^{\mathrm{b}}$ \\
7.5 & $75.13^{\mathrm{a}}$ & $2.02^{\mathrm{b}}$ & $23.79^{\mathrm{a}}$ \\
\hline a,b,c Means with different letters within the same column differ significantly $(\mathrm{P}<0.05)$.
\end{tabular}

that no significant differences were present $(p>0.05)$. Values of $77.32,1.68$ and 24.69 were found for $\mathrm{L}^{*}, \mathrm{a}^{*}$ and $\mathrm{b}^{*}$, respectively, corresponding to the control, and values of $71.03,2.21$ and 22.48 were found for the sample with a $4 \%$ addition of defatted soya, values that are similar to those found in this study. Overall, the additions of Lupinus flour ranging from $2.5 \%$ to $7.5 \%$ tended to produce a white coloring, with all treatments presenting high $\mathrm{L}^{\star}$ values. With respect to the color yellow $\left(\mathrm{b}^{*}\right)$, the $2.5 \%$ sample showed values equal to the control, whereas at higher percentages, the values were higher. Therefore, the addition of Lupinus albus flour up to a fortification level of $2.5 \%$ did not significantly affect color, contrary to what was found in the $7.5 \%$ treatment, where a slight increase in the $b^{*}$ values was observed. This is attributed to the yellow color of the Lupinus flour, which comes from carotenoids. Porras-Saavedra (2006) mentioned that the seeds of Lupinus albus and Lupinus montanus have a high carotenoid content. In a study by Figueroa-Cárdenas et al. (2001), the use of $4 \%$ defatted soya in corn tortillas was recommended because, at higher percentages, it produces a dark color. Moreover, Amador-Pérez (2009) reported that the color intensity is reflected in the final product with the increase in the ratio of legume-based flour. Nasar-Abbas \& Jayasena (2012) showed that the yellow color increased with the increase of lupin flour.

\section{Conclusions}

The addition of Lupinus flour resulted in an increase in protein and lysine content, which were highest in the 2.5, 5 and 7.5\% treatments, in which a lysine content of $10.45,11.25$ and $12.02 \%$ was found, respectively. Based on the parameters obtained in the Texture Profile Analysis, the optimal replacement percentage for nixtamalized corn flour doughs is $5 \%$ or lower since higher concentrations increasingly affect the textural properties. The Texture Profile Analysis and quality analysis of the tortillas revealed that the treatments that showed the most desirable characteristics were 2.5 and $5 \%$. During the sensory color analysis, consumers showed a preference for the $2.5 \%$ treatment, which suggests that Lupinus may be a viable new alternative for fortification.

\section{Acknowledgements}

This research is supported, in part, by the Hidalgo Autonomous University, and the authors are also grateful to the National Council of Technology for providing grants.

\section{References}

Agama-Acevedo, E., Rendón Villalobos, R., Tovar, J., Paredes López, O., Islas-Hernández, J. J. \& Bello-Pérez, L. A. (2004). In vitro starch digestibility changes during storage of maize flour tortillas. Nahrung/ Food, 48(1), 38-42.
Almeida, H., \& Loyd, W. (1996). Avances en la manufactura de productos de maíz nixtamalizado. Industrie Alimentari, 18, 4-13.

Amador-Pérez, A. P. (2009). Desarrollo y evaluación de una tortilla de maíz con dos concentraciones de harina de soya (Glicine max) y harina de amaranto (Amarantus hipochondriacus). (Tesis de Licenciatura). Universidad Zamorano, Honduras.

Association of Official Analytical Chemists - AOAC. (1995). Official Methods of Analyses (16th ed.). Washington: Association of Official Analytical Chemists.

Bedolla, S., \& Rooney, L. W. (1984). Characteristics of U.S. and mexican instant maize flours for tortilla and snack preparation. Cereal Foods World, 29, 732-735.

Chen, W. Z., \& Hoseney, R. C. (1995). Development of an objective method for dough stickiness. Lebensmittel-Wissenschaft + Technologie, 28(5), 467-473. http://dx.doi.org/10.1006/fstl.1995.0079.

Chirinos-Arias, M. C. (2015). Andean Lupin (Lupinus mutabilis Sweet) a plant with nutraceutical and medicinal potential. Revista Biologia Ciencia., 3, 163-172.

Cuevas-Martínez, D., Moreno-Ramos, C., Martínez-Manrique, E., Martínez, M. E. \& Méndez, A. A. (2010). Nutrition and texture evaluation of maize white common bean nixtamalized tortillas. Interciencia, 35, 828-832.

Day, L. (2013). Proteins from land plants - potential resources for human nutrition and food security. Trends in Food Science \& Technology, 32(1), 25-42. http://dx.doi.org/10.1016/j.tifs.2013.05.005.

DeHaan, L. R., Sanford, W., David, T., \& Fornara, D. (2010). Agricultural and biofuel implications of a species diversity experiment with native perennial grassland plants. Agriculture, Ecosystems \& Environment, 137(1-2), 33-38. http://dx.doi.org/10.1016/j.agee.2009.10.017.

Doxastakis, G., Zafiriadis, I., Irakli, M., \& Tananahi, C. (2002). Lupine, soya and triticale addition to wheat flour doughs and their effects on rheological properties. Food Chemistry, 77(2), 219-227. http:// dx.doi.org/10.1016/S0308-8146(01)00362-4.

Figueroa Cárdenas, J. D., Acero Godinez, M. G., Vasco Méndez, N. L., Lozano Guzmán, A., Flores Acosta, L. M., \& González-Hernández, J. (2001). Fortificación y evaluación de tortillas de nixtamal. Archivos Latinoamericanos de Nutricion, 51(3), 293-302. PMid:11791483.

Flores-Farías, R. (2004). Efecto de la incorporación de fibra dietética de diferentes fuentes sobre propiedades de textura y sensoriales en tortillas de maíz (Zea mays L) (Tesis de maestría). CICATA, Unidad Querétaro, México. Disponible en: https://tesis.ipn.mx/ handle/123456789/952? show=full.

Gasca-Mancera, J. C., \& Casas-Alencáster, N. B. (2007). Addition of nixtamalized corn flour to fresh nixtamalized corn masa. effect on the textural properties of masa and tortilla. Revista Mexicana de Ingeniería Química, 6, 317-328.

Gomez, M. C., Waniska, R. D., \& Rooney, L. W. (1991). Starch characterization of nixtamalized corn flour. Cereal Chemistry, 68, 578-582.

Güémes-Vera, N., Peña-Bautista, R. J., Jiménez-Martínez, C., DávilaOrtiz, G., \& Calderón-Domínguez, G. (2008). Effective detoxification and decoloration of lupinus mutabilis seed derivatives, and effect of these derivatives on bread quality and acceptance. Journal of the Science of Food and Agriculture, 88(7), 1135-1143. http://dx.doi. org/10.1002/jsfa.3152.

Gutiérrez-Dorado, R., Milán-Carrillo, J., Valdez-Ortiz, A., LópezValenzuela, J. A., Mora-Rochín, S., López-Cervantes, J., \& ReyesMoreno, C. (2010, noviembre 8-13). Harinas y tortillas de maíz (zea mays l) transgénico de alta calidad proteínica extrudido. Propiedades Tecnológicas y Nutricionales. In VII Congreso del Noroeste y III 
Nacional de Ciencias Alimentarias y Biotecnología (pp. 391-413). México: Centro de las Artes de Sonora.

López, E. P., \& Goldner, M. C. (2015). Influence of storage time for the acceptability of bread formulated with lupine protein isolate and added brea gum. Lebensmittel-Wissenschaft + Technologie, 64(2), 1171-1178. http://dx.doi.org/10.1016/j.lwt.2015.07.013.

Martínez-Flores, H. E., Martínez Bustos, F., Figueroa, C. J. D., \& González Hernández, J. (1998). Tortillas from extruded masas as related to corn genotype and milling process. Journal of Food Science, 63(1), 130-133. http://dx.doi.org/10.1111/j.1365-2621.1998.tb15692.x.

Méndez-Montealvo, G., García-Suárez, F. J., Paredes-López, O., \& BelloPérez, L. A. (2008). Effect of nixtamalization on morphological and rheological characteristics of maize starch. Journal of Cereal Science, 48(2), 420-425. http://dx.doi.org/10.1016/j.jcs.2007.10.007.

México. Secretaría de Agricultura, Ganadería, Desarrollo Rural, Pesca y Alimentación - SAGARPA. Servicio de información agroalimentaria y pesquera - Siap (2015). Producción Agrícola. México :Siap. Disponible en:https://www. gob.mx/siap/acciones-y-programas/ produccion-agricola-33119.

Nasar-Abbas, S. M., \& Jayasena, V. (2012). Effect of lupin flour incorporation on the physical and sensory properties of muffins. Quality Assurance and Safety of Crops \& Foods, 4(1), 41-49. http:// dx.doi.org/10.1111/j.1757-837X.2011.00122.x.

Organización Mundial de la Salud - OMS. (2009). Recomendaciones sobre la fortificación de las harinas de trigo y maíz. Informe de reunión: Declaración de Consenso. Geneva: OMS. Disponible en: https://www.who.int/nutrition/publications/micronutrients/ wheat_maize_fort_es.pdf

Ortega-David, E., Rodríguez, A., David, A., \& Zamora-Burbano, A. (2010). Caracterización de semillas de lupino (Lupinus mutabilis) sembrado en los andes de Colombia. Acta Agronomica, 59, 111-118.

Paraskevopoulou, A., Chrysanthou, A., \& Koutidou, M. (2012). Characterization of volatile compounds of lupin protein isolateenriched wheat flour bread. Food Research International, 48(2), 568-577. http://dx.doi.org/10.1016/j.foodres.2012.05.028.

Paredes-López, O., Guevara-Lara, F., \& Bello-Pérez, L. A. (2009). La nixtamalización. Ciencias., 92, 60-70.

Porras-Saavedra, J. (2006). Identificación química de las características de lupinus ssp silvestres del estado de Hidalgo y de L. albus para la fortificación de alimentos (Tesis de Licenciatura). UAEH-ICAP, Tulancingo de Bravo, Hidalgo, México.

Rangel-Meza, E., Muños-Orozco, A., Vázquez Carrillo, G., Cuevas Sánchez, J., Merino Castillo, J., \& Miranda Colín, S. (2004).
Nixtamalización, elaboración y calidad de tortilla de maíces de Ecatlán, Puebla, México. Agrociencia, 38, 53-61.

Rendón-Villalobos, R., Ortíz-Sánchez, A., Solorza Feria, J. \& TrujilloHernández, A. (2012). Formulation, physicochemical, nutritional and sensorial evaluation of corn tortillas supplemented with chía seed (Salvia hispanica L.). Journal of Food Science, 30, 118-125.

Rodríguez-Sandoval, E., Fernández-Quintero, A., \& Ayala-Aponte, A. (2005). Reología y textura de masa: aplicaciones en trigo y maíz. Ingenieria e Investigacion, 57, 72-78.

Ruíz, M. A., \& Sotelo, A. (2001). Chemical composition nutritive value and toxicology evaluation of mexican wild Lupin. Journal of Agricultural and Food Chemistry, 49(11), 5336-5339. http://dx.doi. org/10.1021/jf010247v. PMid:11714325.

Sobral, P. J. A., Menegalli, F. C., Hubinger, M. D., \& Roques, M. A. (2001). Mechanical, water vapor barrier and thermal properties of gelatin based edible films. Food Hydrocolloids, 15(4-6), 423-432. http://dx.doi.org/10.1016/S0268-005X(01)00061-3.

Suhendro, E. L., Almeida-Dominguez, H. D., Rooney, L. W., Waniska, R. D., \& Moreira, R. G. (1999). Use of extensibility to measure corn tortilla Texture. Cereal Chemistry, 76(4), 536-540. http://dx.doi. org/10.1094/CCHEM.1999.76.4.536.

Torres, F., Moreno, E., Chong, I., \& Quintanilla, J. (1996). La industria de la masa y la tortilla: desarrollo y tecnología. México: Programa Universitario de Alimentos - UNAM.

Vázquez Rodríguez, J. A., \& Amaya Guerra, C. A. (2010, Mayo 27-28). Evaluación sensorial de tortillas de maíz fortificadas con harina de amaranto, frijol y nopal. In XII Congreso Nacional de Ciencia y Tecnología de Alimentos (pp. 111-117). Guanajuato México: Universidad Autónoma de Nuevo León.

Vázquez-Rodríguez, J. A., Amaya Guerra, C. A., Báez Gonzáles, J. C., \& Nuñez Gonzáles, M. A. (2011). Fortificación de tortillas de maíz con harinas de frijol, amaranto y nopal y su evaluación proteica durante 2 generaciones. In Simposium Internacional sobre Tecnologías Convencionales y Alternativas en el procesamiento del Maíz (pp. 126-132). Chihuahua, México

Villarino, C. B. J., Jayasena, V., Coorey, R., Chakrabarti-Bell, S., Foley, R., Fanning, K., \& Johnson, S. K. (2015). The effects of Lupin (Lupinus angustifolius) addition to wheat bread on its nutritional, phytochemical and bioactive composition and protein quality. Food Research International, 76, 58-65. http://dx.doi.org/10.1016/j. foodres.2014.11.046.

Villavicencio, M. A., \& Pérez-Escandón, B. E. (1998). Lista florística del estado de Hidalgo. recopilación bibliográfica. Pachuca: UAEH. 